\title{
SCJ トヒック
}

\section{日本学術会議第177回総会を開催}

日本学術会議第 177 回総会が、平成 30 年 10 月 3 日 (水) $~ 5$ 日 (金)の三日間にわたり開催されました。 初日の3日には、東京大学社会科学研究所教授であり、同大学の副学長でもあられる大沢真理先生（日 本学術会議連携会員) が「Society 5.0への諸課題」と題して特別講演を行いました。二日目の4日には、 平井卓也内閣府特命担当大臣（科学技術政策担当）がご出席され、ご挨拶をいただきました。

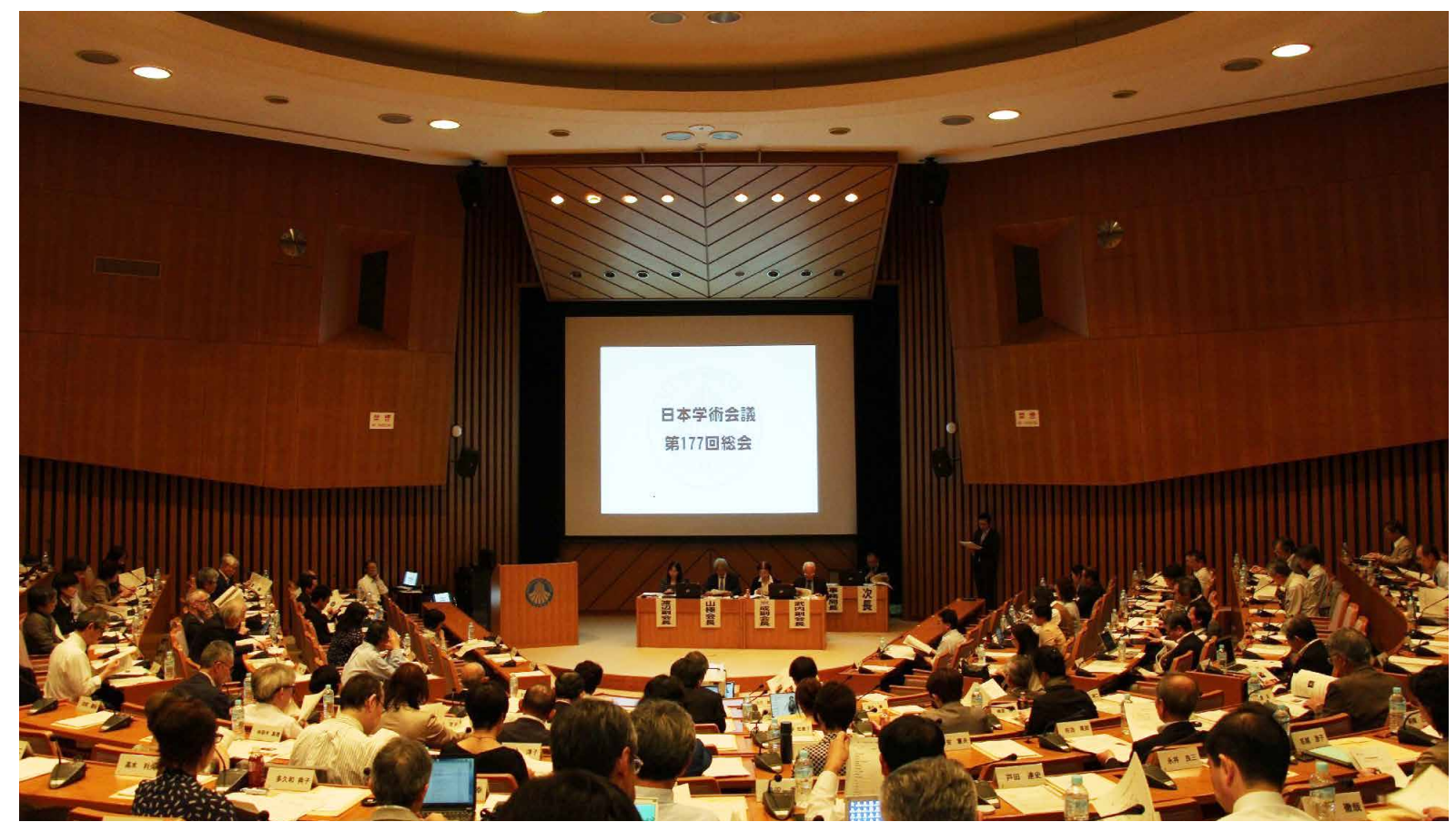

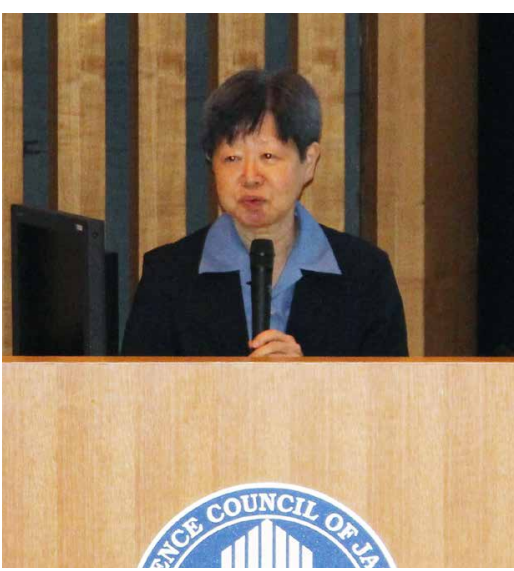

大沢真理先生
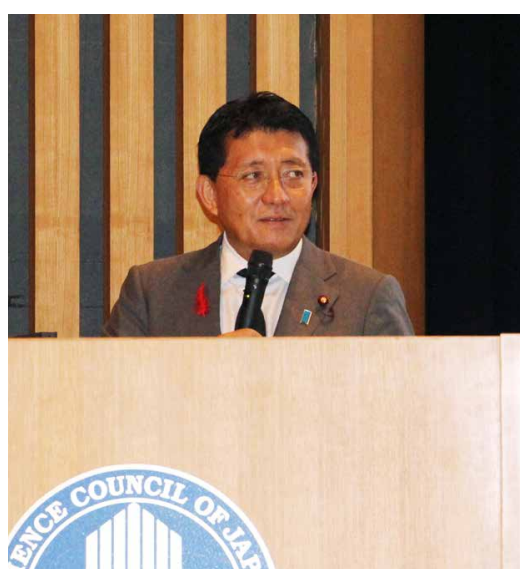

平井卓也内閣府特命担当大臣 